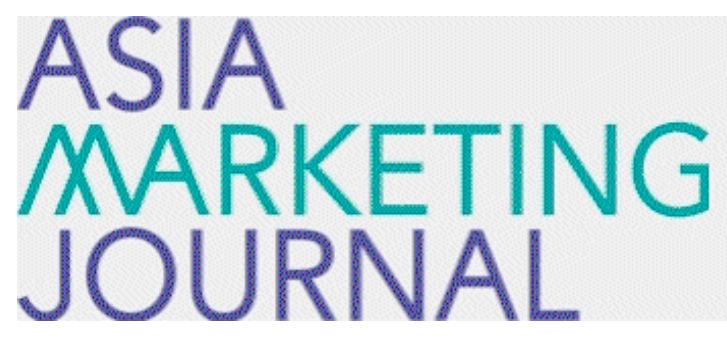

ASIA MARKETING JOURNAL

Volume 14 | Issue 4

Article 8

$1-30-2013$

\title{
The Benefits of Sales Force Automation Explored
}

Jeong Eun Park

Betsy Bugg Holloway

Sung Ho Lee

Follow this and additional works at: https://amj.kma.re.kr/journal

Part of the Marketing Commons

\section{Recommended Citation}

Park, Jeong Eun; Holloway, Betsy Bugg; and Lee, Sung Ho (2013) "The Benefits of Sales Force Automation Explored," Asia Marketing Journal: Vol. 14 : Iss. 4 , Article 8.

Available at: https://doi.org/10.53728/2765-6500.1504

This Article is brought to you for free and open access by Asia Marketing Journal. It has been accepted for inclusion in Asia Marketing Journal by an authorized editor of Asia Marketing Journal. 


\title{
The Benefits of Sales Force Automation Explored: An Empirical Examination of SFA Usage on Relationship Quality and Performance
}

\author{
Jeong Eun Park* \\ Betsy Bugg Holloway** \\ Sungho Lee***
}

Sales force automation (SFA) technologies are increasingly used to support customer relationship management (CRM) strategies. However, the popular press reports mixed results among companies incorporating SFA technologies and the previous studies have less interested in relationship quality between sales person and customer as an outcome of SFA. Actually the improved quality of the salesperson-customer relationship may be the most important outcome of SFA usage. This outcome is especially meaningful in today's marketplace given the increasing focus placed on customer retention and other customer related performance such as customer lifetime value.

Therefore, this study seeks to further examine the impact of SFA usage within two different firms using SFA technologies to examine the impact of SFA usage on both customer relationship quality and sales performance. Additionally, the moderating roles of perceived managerial support and salesperson experience on the outcomes of SFA usage are examined.

The results shows that direct effect of SFA usage on performance was not significant but highlight the mediating role of customer relationship quality in the SFA usage - sales performance relationship. Also, this research examines a number of moderating effects of both management supports for SFA and salesperson's sales work experience. The results indicate that management support has a significant direct influence on relationship quality and salesperson performance, but not a significant moderating effect on the relationship between SFA usage and the outcomes (relationship quality and performance). Thus moderating effects were not supported but find significant main effects. First of all, finding of this study suggest that a formula for successful SFA implementation must be one that highlights a SFA usage $\rightarrow$ relationship quality $\rightarrow$ sales performance sequence. This means when sales person use SFA they must build relationship with customer first then will return some long

\footnotetext{
* Associate Professor of Marketing. Ewha School of Business Ewha Womans University(jepark@ewha.ac.kr), Corresponding Author

** Associate Professor, Samford University(bbhollow@samford.edu)

*** Professor of Marketing. College of Business Administration University of Seoul(shlee@uos.ac.kr)
} 
term performance. Second, the implications of not considering the introduction of big technology initiatives in terms of fit within the company's culture, strategy, structure, and environment may in many cases be quite noteworthy. Therefore, the launching of a new technology in the fimr, such as SFA, may have a nonlinear impact upon overall firm performance, depending on the presence of other complimentary resources and capabilities.

Finally the authors offer a number of implications for research and practice, and suggest directions for future SFA research that may further improve our understanding of this increasingly relevant topic.

Key words: Customer Relationship Management (CRM), Sales force Automation (SFA), Relationship Quality, Sales Performance

\section{Introduction}

In today's competitive environment, success increasingly hinges on the ability to leverage customer relationships in order to acquire information that enables the development and implementation of more efficient and effective customer-focused strategies (Hansotia, 2002). The firm's sales force - as a key boundary spanning activity - plays a critical role in building mutually beneficial, long-term customer relationships (Weitz \& Bradford, 1999). Based upon this representation of the salesperson's expanded role, it is easy to see why many firms today are attracted to the enhanced communication and information access represented by CRM-related technologies. In fact, the CRM market for sales-related e-commerce applications grew from $\$ 9.29$ billion in 2009 to $\$ 10.6$ billion in 2010 and $\$ 12$ billion in 2011 in terms of worldwide revenue of top $10 \mathrm{CRM}$ software vendors according to Gartner report (2012), showing a steady growth of over $10 \%$ annual growth rate (softwarestrategiesblod.com. 2012).

Proponents of technology use by sales forces have long advocated the potential for sales force automation (SFA) to increase productivity (e.g., Moriarty \& Swartz, 1989: Wedell \& Hempeck, 1987). While early reports almost universally heralded the enhanced efficiency and quick return on investment resulting from the implementation of SFA systems (Colombo, 1993; Swenson \& Parella, 1992), however, more recent findings suggest that a startling percentage - upwards of 70 percent - of SFA projects have been unsuccessful (Ericson, 2001: Rivers \& Dart, 1999). Several notable studies have sought to explain these mixed results by positioning the problem as chiefly one of failed or incomplete adoption of the technology by the sales force (e.g., Keillor, Bashaw, \& Petijohn, 1997: Rivers \& Dart, 1999: Jones, Sundaram, 
$\&$ Chin 2002). A recent stream of research has focused on the importance of determinant variables influencing the likelihood of successful technology adoption or elevating the extent of the usage of SFA systems (e.g., Ahearne, Jelinek, \& Rapp, 2005: Avlonitis \& Panagopoulos, 2005: Bush, Moore, \& Rocco, 2005: Jones et al., 2001: Schillewaert, Ahearne, Frambach, \& Moenaert, 2005: Rangarajan, Jones, \& Chin 2005). The determinants commonly examined include perceived usefulness, perceived ease of use, supervisor encouragement and support, salesperson training, salesperson innovativeness, and threats from competitors. Jones et al. (2001) point to low usage of the system, as opposed to adoption per se, in explaining this "productivity paradox (Venkatesh \& Davis, 2000, p. 186)." Perhaps the primary difficulty with understanding these results is that little scholarly work has investigated the SFA-performance link (Stoddard, Clopton, \& Avila, 2002).

In particular, there remains a need for research to examine the impact of SFA usage on customer relationship quality. Indeed, the improved quality of the salesperson-customer relationship may be the most important outcome of SFA usage. This shortcoming is especially meaningful in today's marketplace given the increasing focus placed on retention, customer equity and customer lifetime value (Rust, Lemon, \& Narayandas, 2004). An improved understanding of relationship quality in the context of SFA deployment should allow for more effective management of the entire SFA system. Therefore, in order to build from these findings and further examine the benefits of SFA deployment, this study aims to improve our understanding of the performance impact of SFA usage by empirically examining how SFA technology influences customer relationship quality and sales performance from the perspective of salespeople. Additionally, we explore the moderating roles of both perceived managerial support and salesperson experience on the outcomes of SFA usage. In so doing, we consider the following research questions:

1. What is the influence of sales force automation on customer relationship quality, and does either perceived management support or salesperson experience moderate this relationship?

2. What is the influence of sales force automation on sales performance? And does either perceived management support or salesperson experience moderate this relationship?

The remainder of the paper is organized as follows. First, we first present a conceptual model illustrating the relationships between our focal constructs of interest and introduce the related hypotheses. The research methods and results are then presented. Finally, the paper concludes with a discussion of managerial and research implications, limitations, and directions 
〈Figure 1〉 A Conceptual Model of SFA and Salesperson's Outcomes

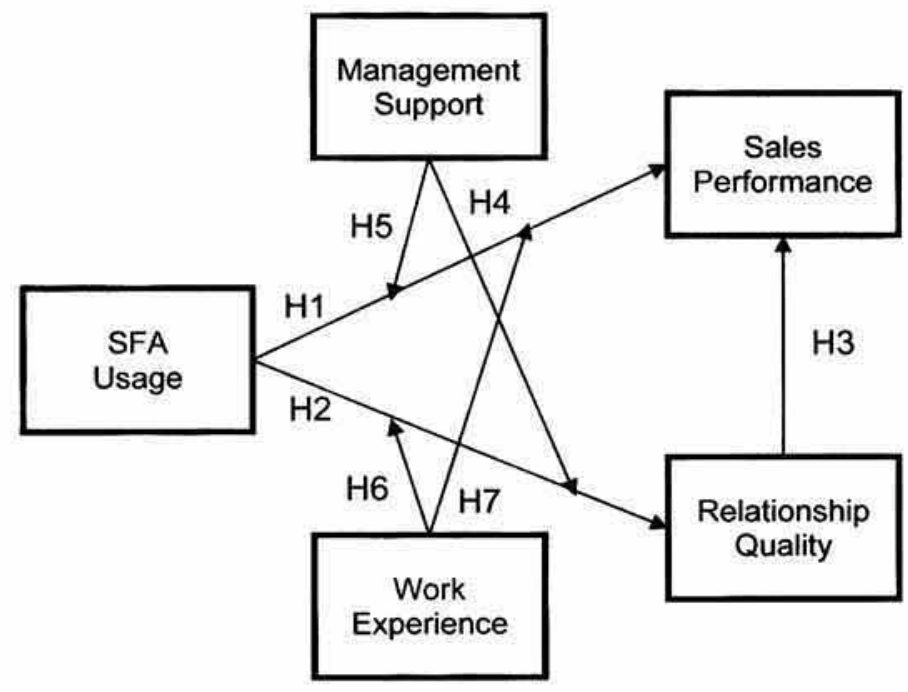

for future research.

Figure 1 illustrates the conceptual model presented by our study. First, the model highlights the relationship between SFA usage and customer relationship quality. SFA usage is proposed to positively influence sales performance, both directly and indirectly through customer relationship quality. Additionally, the moderating roles of perceived managerial support and salesperson experience on the outcomes of SFA usage are included.

\section{Conceptualizing the Hypotheses}

\subsection{SFA Usage and Sales Performance}

As discussed previously, the link between
SFA usage and improved performance remains a matter of debate. An alarming number of reports have pointed to high rates of failure among companies adopting SFA. Analysts from IT research companies such as META and the Gartner Group generally suggest failure rates between 55 and 70 percent for all CRM implementations (Ericson, 2001). Another recent report found less than $50 \%$ of sales reps are using their CRM/SFA system the way sales management would like and that only $20 \%$ of sales managers would characterize their CRM or SFA system as "very successful" (AvantGo, 2002). Successful SFA implementation requires significant change in organizational form and function (Morgan and Inks, 2001) - hence, potential explanations for the failure of any given SFA implementation may be numerous and complex. For example, inadequate training 
is a commonly cited reason for poor SFA outcomes. Ahearne et al. (2005) showed that under the low level of user training and support, the use of sales force automation tools actually reduced salesperson efficiency and effectiveness. Another recent study reported that $25 \%$ of firms offered no training to support their SFA effort, and those who did significantly underestimated the amount of training - and related costs, time and missed opportunities - needed to master the system (Erffmeyer \& Johnson, 2001). In other cases, management expectations regarding SFA outcomes may be unrealistic or over-inflated by trade press accounts and the ambitious claims of eager vendors. Some firms might hastily adopt the technology due to institutional pressures, neglecting the need for building up adequate IT infrastructure or the supporting norms and values (e.g., market orientation) required to drive effective SFA use. Similarly, differences in the perceptions and expectations held by management and salespeople toward SFA can affect the successful adoption and implementation of the system (Gohmann et al., 2005). In fact, Honeycutt et al. (2005) maintain that high failure rates of SFA implementation are largely due to gaps that exist between the sales force and management with respect to SFA perceptions and goals.

On the other hand, anecdotal evidence as well as the emergence of hundreds of SFA solutions providers lends support to the idea that SFA usage can positively impact sales performance. Practitioners and scholars suggest SFA technologies enhance performance by increasing the efficiency and productivity of salespeople and by improving both the quality and the quantity of communications between the salesperson, the buying organization, and the selling firm (e.g., Colombo, 1993: Swenson \& Parella, 1992: Keillor et al., 1997). SFA systems have been shown to improve productivity by reducing travel time and paperwork, improving sales planning, and engendering more effective sales calls (Wedell \& Hempeck, 1987). Additionally, Taylor (1993) reports SFA supplies salespeople with faster access to information, reducing preparation time for client presentations and leading to fewer follow-ups for additional information. Moreover, research has shown that SFA systems are associated with reduced sales support costs, improved closure rates, and an increase in the average selling price through more timely and accurate pricing information (Verity, 1993). In a national survey of industrial salespeople, Keillor et al. (1997) reports that $70 \%$ of respondents agree to the statement of using computers in sales and marketing is essential because they give you a competitive edge. Despite the anecdotal evidence of high failure rate with SFA, as SFA usage increases, sales performance increases along with improvement in efficiency and effectiveness of sales activities. The following hypothesis results from this discussion: 
H1: SFA usage is positively related to sales performance.

\subsection{SFA Usage, Customer Relationship Quality, and Sales Performance}

The relationship quality construct has been used extensively throughout the marketing literature in studying relationships between buyers and sellers (e.g., Boles, Johnson, \& Barksdale, 2000: Dorsch, Swanson, \& Kelley, 1998: Dwyer, Schurr, \& Oh, 1987: Jap, Manolis, \& Weitz, 1999: Kumar, Scheer, \& Steenkamp, 1995), customers and service personnel (e.g., Crosby, Evans, \& Cowles, 1990: Lagace, Dahlstrom, \& Gassenheimer, 1991), and customers and service firms (e.g., Hennig-Thurau \& Klee, 1997; Hennig-Thurau, Gwinner, \& Gremler, 2002), and is rooted in the concept of relationship marketing (Morgan \& Hunt, 1994). Salespeople usually maintain a portfolio of varied relationships with their customers (Lambe \& Spekman, 1997). Research supports the notion of a continuum of customer relationships, ranging from one-time, transactional relations to strong, highly committed relationships (Dwyer et al. 1987: Garbarino \& Johnson, 1999: Jackson, 1985). While transactional exchanges may dominate the portfolio of most salespeople, relational exchanges are thought to provide the greatest opportunity for developing strategic advantage and realizing superior profits (Choi, Kim and Lee, 2001: Weitz \& Bradford, 1999).
Thus, almost by definition, the overriding goal of any CRM initiative typically involves improving the quality of relationships the firm has with its customers. The increased rate of new product introductions and greater complexity of many new products combined with the increased length and intricacy of the selling process itself have only served to elevate the emphasis on strategic customer relationship management (Weitz \& Bradford, 1999). This heightened focus on buyer-seller relationships has led to the concept of the selling center or team that interfaces with the buying center across functions and management levels (Cespedes, 1994: Moon \& Gupta, 1997). In essence, salespeople have become relationship managers, charged with managing teams as opposed to simply their own activities (Webster, 1992).

This study defines relationship quality as the magnitude, degree or extent of a customer relationship with a service provider and conceptualizes relationship quality as a second- order latent construct encompassing both trust and commitment, consistent with rich prior literature of relationship quality (e.g.. Crosby et al., 1990). It is generally agreed that relationship quality is an overall construct which is based on all previous experiences and impressions the customer has had with the service provider (e.g., Hennig-Thurau \& Klee, 1997). As such, the measurement of the customer's evaluation at any specific point in time is thought to be cumulative, extending beyond a single episode 
evaluation. As explained by Bove \& Johnson (2001): "In both a consumer and industrial market setting, central to the measurement of the magnitude of a relationship between a customer/buyer and service personnel/provider/ seller are the variables trust and commitment (p. 191)," relationship quality has been conceptualized and measured to reflect trust and commitment cumulatively built between a buyer and a seller.

We propose that salesperson learning resulting from greater SFA usage is likely to improve the quality of customer interactions that follow. SFA systems provide the salesperson with immediate access to real-time, integrated information that can be used in any number of ways to improve customer relationship quality. While the SFA may not provide all the answers, it quite often will suggest the right questions to ask. For example, salespeople can review past customer purchase and payment histories in order to ask questions that improve their understanding of existing customer needs as well as address future requirements. Alternatively. greater access to knowledge held elsewhere in the sales organization (e.g., peers, managers, technical staff) can be crucial in helping the salesperson build customer trust and commitment as well as ward off competitors. These arguments all suggest a positive relationship between SFA usage and customer relationship quality. The following hypothesis results from the previous discussion:
H2: SFA usage is positively related to customer relationship quality.

Moreover, we propose that customer relationship quality is positively related to sales performance. A wide range of studies have considered the benefits of relationship marketing. That is, measures of relationship quality are directly related to customer loyalty (e.g., Gwinner, Gremler, \& Bitner, 1998), relationship stability (e.g., Hennig-Thurau \& Klee, 1997), customer retention (e.g., Morgan \& Hunt, 1994; Sheth \& Parvatiyar, 1995), positive word of mouth referral behavior (e.g.. Bendapudi \& Berry, 1997), and longer-term orientation between firms (e.g., Ganesan, 1994). Within the sales literature, research shows that a positive customer-salesperson relationship contributes to higher levels of customer loyalty and intention to continue the relationship with the salesperson (Crosby et al, 1990: Macintosh \& Lockshin, 1997). In one recent study supporting the customer relationship quality-performance link, Jap (2001) found that trust built between industrial salespeople and customers increasingly influences satisfaction over the course of the relationship life-cycle. The following hypothesis results from the previous discussion:

H3: Customer relationship quality is positively related to sales performance. 


\subsection{The Moderating Influence of Management Support for SFA and Salesperson Experience}

In addition to the proposed hypotheses, our study also provides the opportunity to examine the impact of two potential moderating variables: management support for the SFA and salesperson experience. In order to examine the potential roles of both, we consider a number of moderating effects on the relationships previously posited. Management support has been shown to favorably influence individual perceptions of a technology (Jarvenpaa \& Ives, 1991). including perceptions of sales force automation initiatives (Avlontis \& Panagopoulos, 2005: Gohmann et al., 2005: Schillewaert et al., 2005). In the context of CRM technologies, Croteau \& Li (2003) examine a number of critical success factors of CRM technological initiatives and find that top management support is crucial for CRM implementation success, concluding, "as related in the literature, if executives do not show any interest or involvement in the whole process, organizations' members will not believe in such projects and will tend to resist instead (p. 12)." Recent empirical research from Ahearne et al. (2005) illustrates that user training and support have a critical moderating influence on salesperson performance. Their research indicates that sales force automation can actually reduce salesperson efficiency and effectiveness under low levels of user training and support. This is further supported by evidence suggesting that when goals and feedback are individualistic (as is typically the case for salespeople), this encourages a learning desire and positive behavior (Brown, 1999). Similarly, goal and control theory suggests that the provision of clear and unambiguous goals focuses one's attention on a task, triggering a search for relevant information and focused behavior that will help them to achieve those goals (cf. Klein, 1989: Locke, Latham \& Erez, 1988). Thus, the following hypotheses result from this discussion:

H4: Management support for SFA will moderate the relationship between SFA usage and customer relationship quality: as management support for SFA increases, the strength of the relationship between SFA usage and customer relationship quality will increase.

H5: Management support for SFA will moderate the relationship between $S F A$ usage and sales performance: as management support for SFA increases, the strength of the relationship between SFA usage and sales performance will increase.

Second, based on some relevant evidence, we predict that salesperson's experience will have a moderating effect on the relationships between both SFA usage and customer relationship quality and SFA usage and sales performance. 
Specifically, use of the SFA system might be more irksome to experienced salespeople, as they are shown to be more set in their routines and less responsive to attempts to influence day-to-day behavior (Johnston et al., 1990: Speier \& Venkatesh, 2002). Additionally, because experienced salespeople possess well-developed scripts for various selling situations (Leigh \& McGraw, 1989), they are more prone to find supervisory intervention bothersome, which thereby diminishes their motivation to learn and benefit from the technology. Thus, experienced salespeople are more likely to perceive the organizational benefits of SFA as being tied to relatively mundane activities, such as filling call reports, as opposed to enhancing the salesperson's ability to develop deeper and more profitable customer relationships. In such instances, SFA implementation may actually lower the salesperson's motivation to learn relative to less experienced peers.

Similarly, in regards to performance, experienced salespeople may be more likely to feel they are losing control if forced to share personal information and to transfer their "know" how" to the company. Less experienced salespeople, on the other hand, tend to value structure and are more receptive to direction from supervisors (Kohli, 1989). Further, because less experienced salespeople may not possess welldeveloped scripts for dealing with various selling situations, they are likely to be less resentful of SFA-related changes in their day-to- day activities. Empirical research from Keillor et al. (1997) suggests that less experienced salespeople generally have a more positive attitude toward computer technology. Further, their research found that firms with more experienced sales teams had greater difficulty in successfully implementing a technology-based sales program. The following hypotheses result from this discussion:

H6: Salesperson experience will moderate the relationship between SFA usage and customer relationship quality: as salesperson experience increases, the strength of the relationship between SFA usage and customer relationship quality will decrease.

H7: Salesperson experience will moderate the relationship between SFA usage and sales performance: as salesperson experience increases, the strength of the relationship between SFA usage and sales performance will decrease.

\section{Methodology}

\subsection{Data Collection}

This study involves a convenience sample of 170 salespeople within North America who were recruited from two different companies based 
in the Southeastern U.S. during the summer of 2011. In recruiting the organizations to participate in the research study, effort was made to select companies from different industries but with highly similar SFA systems and policies regarding its use. Both companies used customdesigned databases to store and retrieve a variety of information related to sales activities and customer accounts with the end goals of maximizing salesperson effectiveness, customer retention, and profitability. In both cases, use of the system was mandatory, and reports must be submitted to the database weekly. However, for both firms, the frequency of retrieval and use of the information stored in the database was left to the discretion of the individual salesperson. Furthermore, the companies were believed to provide a particularly interesting context for this study, as both industries involved a relatively high degree of SFA adoption as well as comparable B2B sales relationships. In other words, the study context was designed to involve with the higher level of internal validity than that of external validity by considering the power of study to be the important issue (i.e., finding the relationships among the constructs of research constructs if there were the relationships).
Data collection occurred online via a web-based questionnaire. Each salesperson was contacted by their national sales director and invited to complete the online questionnaire within a three-week period. In order to encourage participation, for each completed questionnaire we pledged a donation to one of several national philanthropies, with the preference indicated by the individual respondent. This resulted in a response rate of $56 \%$, as 95 of the total 170 salespeople completed the questionnaire. Of these 95 respondents, five were excluded due to incomplete responses leaving a final sample size of 90. As illustrated in Table 1, the sample was almost evenly split between male (43) and female (47) respondents. Further, in terms of experience, the average sales experience was 10.69 years and the average tenure with the participating companies was 5.01 years. It also should be noted that the respondents come from throughout North America, and each of the major regions of the U.S. and Canada are represented in the sample.

\subsection{Measures}

All of the constructs used in this study were drawn from existing literature and adapted for

〈Table 1〉 Key Demographics of Respondents

\begin{tabular}{ccccc}
\hline \multicolumn{2}{c}{ Gender } & $\begin{array}{c}\text { Average Working } \\
\text { Experience with the } \\
\text { company (years) }\end{array}$ & $\begin{array}{c}\text { Average Sales } \\
\text { Experience with the } \\
\text { company (years) }\end{array}$ & $\begin{array}{c}\text { Average Sales } \\
\text { Experience in the } \\
\text { industry (years) }\end{array}$ \\
\hline $43(47.8 \%)$ & $47(52.2 \%)$ & 5.01 & 4.19 & 10.69 \\
\hline
\end{tabular}


the context of this study. With few exceptions, the measures in the questionnaire used 7-point Likert-type scales. The anchors were either "strongly disagree" to "strongly agree" or "very unsatisfied" to "very satisfied." A test of reliability using Cronbach's alpha shows that the measures for each construct exceed Nunnally and Bernstein's (1994) standard of .80 as the lower limit of acceptability for the existing measures.

SFA usage was measured with a four-item 'ease of use' scale adapted from Moore and Benbasat (1991) (alpha $=0.92$ ). Customer relationship quality was measured using a multi-dimensional scale of 9 items to measure trust and commitment (Crosby et al., 1990: Dwyer et al., 1987: Garbarino \& Johnson, 1999; Hennig-Thurau, 2000). The scale exhibited highly acceptable reliability $(a=0.96)$. To measure sales performance, we asked salespeople to evaluate themselves, relative to other salespeople working for their company, on achieving quantity and quality sales objectives. Eight items were used: two were taken from Behrman \& Perreault (1984), and six items were drawn from Sujan, Weitz, \& Kumar's (1994) study to assess salespeople's perceived accomplishments, including generating sales, selling high profit-margin products, selling new products, and customer retention (Park \& Holloway, 2004). The scale exhibited high reliability $(a=0.95)$. Finally, management support for SFA was measured using 3 items adapted from the research of Leonard-Barton \& Deschamps
(1988) and also showed high reliability ( $a=$ 0.93). The other proposed moderator, salesperson experience, was measured using 3 items: years worked with the current company, in the current job position, and in the industry.

\subsection{Measurement Validity}

Structural equation modeling, analyzed using LISREL 8.3, was conducted to test the proposed structural model. Following the two-stage approach suggested by Anderson \& Gerbing (1988), measurement validity of each construct was tested prior to estimating the structural paths to test the hypothesized relationships between the constructs. Because including all items for each construct would result in too complex a model to be estimated easily using LISREL (cf. Anderson \& Narus, 1984: Bentler \& Chou, 1987), we ran structural models with favorable results (Sujan, Weitz, \& Kumar, 1994).

Consistent with Anderson \& Gerbing (1988), all constructs were evaluated based on the following criteria: unidimensionality, reliability, and convergent and discriminant validity. As indicated by the squared multiple coefficient values, all items have a significant loading on their corresponding constructs (the lowest $t$-value was 7.22), demonstrating adequate convergent validity. A pairwise comparison of the constructs in the modification indices indicated that two items from performance cross-loaded into other constructs, resulting in the elimi- 
〈Table 2〉 The Results of Confirmatory Factor Analysis

\begin{tabular}{ccccccccccccc}
\hline Construct & \multicolumn{3}{c}{ SFA Usage } & \multicolumn{4}{c}{$\begin{array}{c}\text { Relationship } \\
\text { Quality }\end{array}$} & \multicolumn{7}{c}{ Performance } \\
\hline Indicator & U1 & U2 & U3 & U4 & T1 & C1 & P1 & P2 & P4 & P5 & P7 & P8 \\
\hline Estimates & 1.306 & 1.479 & 1.534 & 1.222 & 0.851 & 0.748 & 0.880 & 0.774 & 0.842 & 0.963 & 0.887 & 0.780 \\
(t-value) & $(\mathrm{N} / \mathrm{A})$ & $(9.67)$ & $(10.53)$ & $(8.29)$ & $(11.47)$ & $(10.05)$ & $(\mathrm{N} / \mathrm{A})$ & $(7.27)$ & $(7.22)$ & $(8.88)$ & $(8.88)$ & $(8.13)$ \\
\hline SMC & 0.59 & 0.81 & 0.97 & 0.64 & 0.89 & 0.76 & 0.66 & 0.51 & 0.51 & 0.69 & 0.69 & 0.61 \\
\hline
\end{tabular}

Note: SMC: Squared Multiple Correlation

nation of these two items ( $p 3$ and $p 6$ ) from performance. Subsequently, all the latent-trait correlations between constructs are significantly different than one, establishing discriminant validity. The CFA results are depicted in Table 2.

Moreover, we did the Harman one-factor test to assess the potential for common method bias in the data (Podsakoff and Organ 1986). After the careful item purification, an un-rotated factor analysis of the dependent and independent variables results in a solution that accounts for $82.35 \%$ of the total variance, and the first factor accounts for $37.31 \%$ of the variance. Therefore. common method variance bias is unlikely to be a concern. In addition, the questionnaire was very carefully designed from the beginning. Common method bias usually arises from having a common rater or from the characteristics of the items themselves (Podsakoff, MacKenzie, Lee and Podsakoff 2003). We allowed the respondents' answers to be anonymous and assured them that there were no right or wrong answers and they answer the questions as honest as possible. This procedure must have reduced the respondents' evaluation apprehension and the tendency of being socially desirable which is also an arguable source of common method effects produced by a common rater (Podsakoff et al. 2003).

\section{Hypothesis Analysis}

In the second stage of measurement analysis, information from the test of measurement validity was used to help estimate the overall structural model. To examine the structural relationships, the hypothesized main effect model in Figure 2 was estimated and resulted. The $x^{2}$ (with 49 degrees of freedom) was not significant (57.71, $\mathrm{p}=0.18$ ), and the $\mathrm{CFI}$ of 0.957 was satisfactory with the $x^{2} / \mathrm{df}$ ratio below 2.0, confirming that the our data fitted the proposed structural model very well. Other goodness of fit statistics were also favorable, considering the commonly accepted cutoffs of each index (see Table 3).

Among the five hypotheses, three were tested by the structural equation model. Two were 


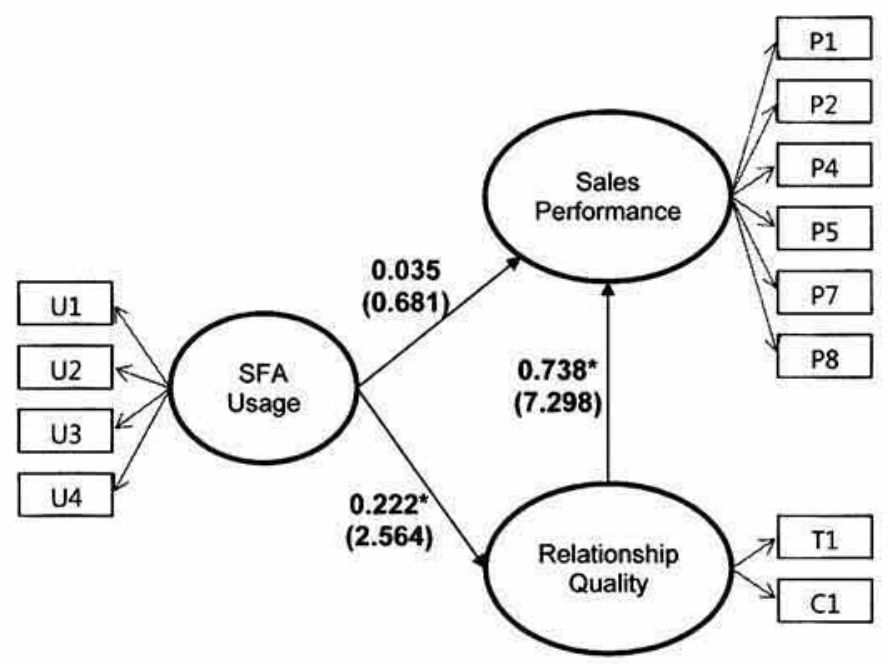

Note: Standardized coefficient and T-value in brackets. T-values greater than 2.00 are significant. ( ${ }^{*}$ indicates that the path is significant at the .05 level)

〈Table 3〉 The Goodness of Fit Statistics for the Measurement and Structural Models

\begin{tabular}{cccccc}
\hline Index & RMSEA & SRMR & NNFI & GFI & AGFI \\
\hline Measurement & 0.04 & 0.05 & 0.98 & 0.91 & 0.85 \\
\hline Structural & 0.04 & 0.05 & 0.98 & 0.91 & 0.85 \\
\hline
\end{tabular}

Note: RMSEA: root mean square error of approximation: SRMR: standardized root mean square residual: NNFI: Non-Normed Fit Index: GFI: Goodness of Fit Index, AGFI: adjusted GFI

highly significant while one was not significant. Hypothesis 1, which predicted a positive direct relationship between SFA usage and sales performance, was not supported $\left(\gamma_{11}=0.04\right.$ : $\mathrm{t}$ $=0.68, \mathrm{p}<.15)$. However, SFA usage did have a significant total effect on sales performance with indirect effects through relationship quality (total effect $=0.19: t=$ 24.63, p <.01 and indirect effect $=0.15$ : $\mathrm{t}=23.15, \mathrm{p}<0.01$ ). Hypothesis 2 posited a positive relationship between SFA usage and relationship quality and was supported $\left(\gamma_{21}=\right.$
0.22.: $\mathrm{t}=2.56, \mathrm{p}<.05)$. Hypothesis 3 posited the salesperson's relationship quality had a positive influence on sales performance. Our results indicate relationship quality does indeed have the expected positive effect on performance $\left(\beta_{21}=0.74: t=7.30, p<.01\right)$, supporting Hypothesis 3 .

As outlined previously, this research sought to examine a number of moderating effects of both management support for SFA and salesperson experience. The results highlighted in Table 5 and 6 indicate that management sup- 
〈Table 4〉 Relationships Between $Y$ and $X$ Variables

\begin{tabular}{cccc}
\hline Parameter & Hypothesis & Effect (t-value) & Results \\
\hline$\gamma_{11}$ & H1: SFA Usage $\rightarrow$ Performance & $0.04(0.68)$ & Not Support \\
$\gamma_{12}$ & H2: SFA Usage $\rightarrow$ Relationship Quality & $0.22(2.56)$ & Support \\
$\beta_{21}$ & H3: Relationship Quality $\rightarrow$ Performance & $0.74(7.30)$ & Support \\
\hline
\end{tabular}

Note: Standardized coefficient and $\mathrm{t}$-values in parentheses, $\mathrm{t}$-values greater than 2.00 are significant.

port has a significant direct influence on relationship quality and salesperson performance, but not a significant moderating effect on the relationship between SFA usage and the outcomes (relationship quality and performance). Therefore, while the moderating effects posited in Hypotheses 4 and 5 were not supported, important main effects were found.
Contrary to our hypotheses, our results do not support the influence of salesperson experience on either relationship. As illustrated in Table 7 and 8, our findings indicate that sales experience has neither a significant main effect nor moderating influence upon relationship quality or sales performance. Therefore Hypothesis 6 and 7 are not supported.

〈Table 5〉 Regression Results of Management Support and its Moderating Influence Between SFA Usage and Relationship Quality

\begin{tabular}{cccll}
\hline & Beta & T-value & \multicolumn{1}{c}{ P } & VIF \\
\hline Constant & 6.338 & 71.601 & 0.000 & \\
SFA Usage & 0.025 & 0.379 & 0.706 & 1.431 \\
Management Support & 0.219 & 2.286 & $0.025^{*}$ & 2.581 \\
SFA*Management Support & -0.045 & -1.134 & 0.260 & 2.213 \\
\hline
\end{tabular}

$\mathrm{R}^{2}=0,246$, Dependent Variable $=$ Relationship Quality. Note: VIF $=$ Collinearity Statistic.

* = significant at the $\mathrm{p}<0.05$

〈Table 6〉 Regression Results of Management Support and its Moderating Influence Between SFA Usage and Performance

\begin{tabular}{ccccc}
\hline & Beta & T-value & $\mathrm{P}$ & VIF \\
\hline Constant & 5.747 & 58.069 & 0.000 & \\
SFA Usage & 0.051 & 0.705 & 0.483 & 1.431 \\
Management Support & 0.215 & 2.002 & $0.048^{*}$ & 2.581 \\
SFA*Management Support & -0.033 & -0.745 & 0.459 & 2.213 \\
\hline $\mathrm{R}^{2}=$ 0.198. Dependent variable $=$ Performance, Note: VIF $=$ Collinearity Statistic, ${ }^{*}=$ significant at the $\mathrm{p}<0.05$
\end{tabular}


〈Table 7〉 Regression Results of Salesperson's Experience and its Moderating Influence Between SFA Usage and Relationship Quality

\begin{tabular}{ccclc}
\hline & Beta & T-value & P & VIF \\
\hline Constant & 6.291 & 71.742 & 0.000 & \\
SFA Usage & 0.205 & 3.376 & $0.001^{*}$ & 1.004 \\
Experience & -0.032 & -1.550 & 0.125 & 1.005 \\
SFA*Experience & 0.022 & 1.647 & 0.104 & 1.002 \\
\hline
\end{tabular}

$\mathrm{R}^{2}=0.168$. Dependent variable $=$ Relationship Quality, Note: VIF $=$ Collinearity Statistic,

$*$ = significant at the $\mathrm{p}<0.05$

〈Table 8〉 Regression Results of Salesperson's Experience and its Moderating Influence Between SFA Usage and Performance

\begin{tabular}{ccclc}
\hline & Beta & T-value & $\mathrm{P}$ & VIF \\
\hline Constant & 5.718 & 58.827 & 0.000 & \\
SFA Usage & 0.210 & 3.124 & $0.002^{*}$ & 1.004 \\
Experience & -0.007 & -0.287 & 0.775 & 1.005 \\
SFA*Experience & 0.002 & 0.101 & 0.920 & 1.002 \\
\hline $\mathrm{R}^{2}=0.110$. Dependent variable $=$ Performance, Note: $\mathrm{VIF}=$ Collinearity Statistic, ${ }^{*}=$ significant at the $\mathrm{p}<0.05$
\end{tabular}

\section{Discussion}

\subsection{Summary of the Findings}

The primary objective of this study was to expand our understanding of the relative benefits of SFA usage by empirically examining its effects upon two key outcomes, customer relationship quality and sales performance. Specifically, customer relationship quality was shown to mediate the relationship between SFA usage and sales performance, although the direct effect of SFA usage on sales performance was not identified. Thus, our findings suggest that a formula for successful SFA implementation must be one that highlights a SFA usage $\rightarrow$ relationship quality $\rightarrow$ sales performance sequence. While the earliest generations of SFA projects typically focused on creating greater efficiency by automating existing sales tasks and streamlining administrative duties (e.g.. Wedell \& Hempeck, 1987), the real benefits of SFA may lie in its ability to shape the manner in which salespeople actually sell. In other words, the positive effect of SFA usage on sales performance may be only through this kind of improvement in effective selling behavior at least in the context of our study sample. partially explaining that no direct relationship is found 
between SFA usage and sales performance.

Further, inconsistent with previous research (Ahearne et al., 2005), we fail to find a significant moderating effect of management support on the relationship between SFA usage and the outcomes (relationship quality and performance), though our results indicate that management support has a significant direct influence on both relationship quality and salesperson performance. Thus, while the two hypotheses are not supported, our results are consistent with previous literature by confirming the important role of management support to a successful SFA deployment. The lack of a moderating effect may be explained by the small sample size, or may be due to the small variance $(S . D .=1.31)$ of the managerial support variable.

Moreover, our results fail to support a moderating influence of salesperson experience on the relationships between SFA usage and either customer relationship quality or sales performance. The lack of a moderating effect may be explained by the small sample size, or may be due to the small variance (S.D. $=1.91$ ) of the sales experience in the industry variable. Interestingly, SFA usage was not correlated with sales experience. In other words, given the widespread use of technology in the sales function across industries throughout the past decade. perhaps the age and experience level of the sales person is not as relevant today as it once was when SFA systems were first introduced to the marketplace. Further, perhaps more emphasis should be placed upon the provision of sufficient salesperson training (Ahearne et al., 2005) and the establishment of consistent expectations and perceptions of the sales force automation initiatives throughout the firm (Avlontis \& Panagopoulos, 2005: Gohmann et al., 2005: Schillewaert et al., 2005).

\subsection{Managerial Implications and Future Research Directions}

The results of our study offer a number of meaningful implications for sales managers and scholars. First, although there are many technological components of SFA systems, it is shortsighted to think about CRM and SFA strictly in terms of technology. CRM is a core business strategy, driving success through the management of customer relationship assets, where ongoing investment yields ongoing returns. It involves personalized marketing and service as well as employees whose good judgment and attitude, assisted by technology, turn every customer experience into not just a pleasant interaction but part of an ongoing relationship between each customer and the business. Our results indicate that SFA is best considered as part of a larger relationship making process in which the salesperson's relationship quality is at the core. As such, our findings suggest that it is not the technology per se, but rather the individual relationship build-up that occurs 
through, and as a result of, its utilization that ultimately creates superior performance. Given the central role of salesperson-customer relationship quality, management should focus their SFA planning and design efforts upon maximizing the firm's relationship building capabilities as well as enhancing the salesperson's ability to improve relationships with each customer interaction. Similarly, in assessing prospective SFA purchases, managers would be wise to evaluate systems based on the relative potential of the technology to enhance their salespersons' relationships with customers.

Second, the implications of not considering the introduction of broad technology initiatives in terms of fit within the organization's existing culture, strategy, structure, and environment may in many cases be quite significant. The organizational theory literature is replete with studies signifying the importance of alignment between various aspects of the organization's external and internal environments, particularly its technology (e.g., Park, 2004: Parker, 1995). Strategic management theorists, particularly those from the competence and capabilities literatures, further point out that the process of introducing a new innovation often serves to enhance the firm's ability to build new competences and leverage its existing stock of competences (e.g., Dierickx, Cool, \& Barney. 1989: Prahalad \& Hamel, 1990: Teece, Pisano, \& Shuen, 1997). Thus, the introduction of a new technology, such as SFA, may have a nonlinear impact upon overall firm performance, depending on the presence of other complimentary resources and capabilities. Considered collectively, these schools of thought suggest that determining the impact of a new information technology upon firm and individual performance requires consideration of factors beyond those influencing the dichotomous adoption decision (i.e., nature of the innovation. characteristics of users).

While useful insights have been obtained through this study, future research should aim to overcome a number of limitations. First, from the perspective of generalizability, this research involved two different SFA systems within two firms across two industries. Examining different SFA systems, different firms, and different relationship strategies (e.g., B2C) may have resulted in different outcomes. Further, while this study examines several key benefits of SFA usage, future research should incorporate additional outcomes of SFA deployment and drivers of sales performance, such as adaptive selling behaviors, customer orientation, and job satisfaction. Further, the model and associated hypotheses offered here are all applied and tested from the perspective of the salesperson. Future research should aim to examine these issues from the perspectives of sales managers and customers. Such research would allow a richer and more comprehensive understanding of the benefits of SFA technologies. In addition, while our study examined salesperson's self-perception of per- 
formances due to the limited research resource, the future research had better use more objective performance data with more collaborative efforts with the firms in terms of data collection. Finally, the results for this study are based on a relatively small sample. We acknowledge that additional data will provide better generalizability for our study.

\subsection{Conclusion}

In conclusion, it is hoped that this research contributes to both academicians and business practitioners by improving our understanding of SFA and its benefit for customer relationship quality and sales performance. By examining these vital outcomes of SFA technologies. this study offers a holistic approach to effective SFA deployment. Further, it is evident that relationship quality is the crucial link between the technology and successful outcomes, notably enhanced productivity. Moreover, the results illustrate that management support of these technologies further enhances their benefit. Management therefore should encourage salesperson relationship initiatives through SFA usage in order to maximize organizational performance.

〈Received August 30. 2012〉

〈Revised December 23. 2012〉 〈Accepted December 28. 2012〉

\section{References}

Ahearne, M., R. Jelinek, and A. Rapp (2005), "Moving Beyond the Direct Effect of SFA Adoption on Salesperson Performance: Training and Support as Key Moderating Factors," Industrial Marketing Management, 34(4), 379-388.

Anderson, J.C. and D. Gerbing (1988), "Structural Equation Modeling in Practice: A Review and Recommended Two-Step Approach," Psychological Bulletin, 103(3), 411423.

Anderson, J.C. and J.A. Narus (1984), “Model of the Distributor Perspective of DistributorManufacturer Working Relationships," Journal of Marketing, 48(Fall), 62-74.

AvantGo (2002), 2002 Sales Management and Field Sales Survey, AvantGo, October, 2002 (http://www.avantgo.com/products/ businesses/workforce/applications/pdf/sales _mgmt_survey.pdf).

Avlonitis, G.J. and N.G. Panagopoulos (2005), "Antecedents and Consequences of CRM Technology Acceptance in the Sales Force," Industrial Marketing Management, 34(4), 355-368.

Behrman, D. N. and W.D. Jr. Perreault (1984), "A Role Stress Model of the Performance and Satisfaction of Industrial Salespersons," Journal of Marketing, 48(Fall), 9-21.

Bendapudi, N. and B.B. Berry (1997), "Customers' 
Motivations for Maintaining Relationships with Service Providers," Journal of Retailing, 73(1), 15-37.

Bentler, P. M. and C.P. Chou (1987), "Practical Issues in Structural Modeling," Sociological Methods and Research, 16(1), 78-117.

Boles, J. S., J.T. Johnson, and H.C. Barksdale (2000). "How Salespeople Build Quality Relationships: A Replication and Extension," Journal of Business Research, 48 (1), 75-82.

Bush, A. J., J.B. Moor, and R. Rocc (2005), "Understanding Sales Force Automation Outcomes: A Managerial Perspective," Industrial Marketing Management, 34(4), 369-377.

Cespedes, F. (1994), "Industrial Marketing: Managing New Requirement," Sloan Management Review, 35 (March), 45-60.

Choi, Nak Hwan, Young Ah Kim and Ho Jung Lee (2001), "A Study on The Causes and Outcomes of Relationship - Orientedness between Businesses," Asia Marketing Journal, 3(3), 1-23,

Colombo, G. W. (1993), "The Next Generation," Sales and Marketing Management, 145 (July), 67-69.

Crosby, L. A., K. R. Evans, and D. Cowles (1990), "Relationship Quality in Services Selling: An Interpersonal Influence Perspective," Journal of Marketing, 54(July), 68-81.

Croteau, A.M. and P. Li (2003), "Critical Success Factors of CRM Technological Initia- tives," Canadian Journal of Administrative Sciences, 20(1), 21-34.

Dierickx, I., K. Cool, and J.B. Barney (1989), "Asset Stock Accumulation and Sustainability of Competitive Advantage," Management Science, 35(12), 1504-1513.

Dorsch, M. J., S.R. Swanson, and S.W. Kelley (1998), "The Role of Relationship Quality in the Stratification of Vendors as Perceived by Customers," Journal of the Academy of Marketing Science, 26 (2), 128-42.

Dwyer, F. R., P.H. Schurr, and S. Oh (1987), "Developing Buyer-Seller Relationships," Journal of Marketing, 51, 11-27.

Erffmeyer, R. C. and D.A. Johnson (2001), “An Exploratory Study of Sales Force Automation Practices: Expectations and Realities," Journal of Personal Selling and Sales Management, 21(2), 167-175.

Ericson, J. (2002), "The 'Failure' of CRM," Line56.com, August 02. (htttp://www. line56.com/articles/default.asp?ArticleID $=2$ $808)$.

Ganesan, S. (1994), "Determinants of LongTerm Orientation in Buyer-Seller Relationships," Journal of Marketing, 58, 1-19.

Garbarino, E., \& M.S. Johnson (1999). "The Different Roles of Satisfaction, Trust and Commitment in Customer Relationships," Journal of Marketing, 63, 70-87.

Gohmann, S.F., J. Guan, R.M. Barker, and D. J. Faulds (2005), "Perceptions of Sales Force Automation: Differences Between 
Sales Force and Management," Industrial Marketing Management, 34(4), 337-343.

Gwinner, K. P., D.D. Gremler, and M.J. Bitner (1998), "Relational Benefits in Services Industries: The Customer's Perspective," Journal of the Academy of Marketing Science, 26(2), 101-114.

Hansotia, B. (2002), "Gearing up for CRM: Antecedents to Successful Implementation," Journal of Database Marketing and Customer Strategy Management, 10(2), 121-132.

Hennig-Thurau, T. (2000), "Relationship Quality and Customer Retention through Strategic Communication of Customer Skills," Journal of Marketing Management,16, 55-79. and A. Klee (1997), "The Impact of Customer Satisfaction and Relationship Quality on Customer Retention: A Critical Reassessment and Model Development," Psychology and Marketing, 14(8). 737-764. K.P. Gwinner and D.D. Gremler (2002), "Understanding Relationship Marketing Outcomes: An Integration of Relational Benefits and Relationship Quality," Journal of Service Research, 4 (February), 230-247.

Honeycutt Jr., D. Earl, T. Thelen, S.T. Thelen, and S.K. Hodge (2005), "Impediments to Sales Force Automation," Industrial Marketing Management, 34(4), 313-322.

Jackson, B. B. (1985), Winning and Keeping Industrial Customers, Lexington, MA:
Lexington Books.

Jap, Sandy D. (2001), "Pie-Expansion' Efforts: Collaboration Processes in Buyer-Supplier Relationships," Journal of Marketing Research, 36(4), 461-75.

Jap, S. D., C. Manolis, and B.A. Weitz (1999), "Relationship Quality and Buyer-Seller Interactions in Channels of Distribution," Joumal of Business Research, 46(3), 303-313. Jarvenpaa, S. L. and B. Ives (1991), "Applications of Global Information Technology: Key Issues for Management," MIS Quarterly, 15(1), 205-227.

Jones, E., S. Sundaram, and W. Chin (2001), "Factors Leading to Sales Force Automation Use: A Longitudinal Analysis," Journal of Personal Selling and Sales Management, 22(3), 145-156.

Johnston, M.W., A. Parasuraman, C.M. Futrell, and W. Black (1990), “A Longitudinal Assessment of the Impact of Selected Organizational Influences on Salespeople's Organizational Commitment During Early Employment," Journal of Marketing $\mathrm{Re}^{-}$ search, 27(3), 333-344.

Keillor, B. D.. E.R. Bashaw, and C.E. Pettijohn (1997), “Salesforce Automation Issues Prior to Implementation: The Relationship Between Attitudes toward Technology, Experience and Productivity," The Journal of Business \& Industrial Marketing, 12 (3/4), 209-221.

Klein, H. J. (1989), “An Integrated Control 
Theory Model of Work Motivation," Academy of Management Review, 14(2), 150172.

Kohli, A. K. (1989), "Effects of Supervisory Behavior: The Role of Individual Differences among Salespeople," Journal of Marketing. 53(4), 40-50.

Kumar, N., L.K. Scheer, and J. Steenkamp (1995), "The Effects of Supplier Fairness on Vulnerable Sellers," Journal of Marketing Research, 32 (1), 54-65.

Lagace, R. R. R. Dahlstrom, and J.B. Gassenheimer (1991). "The Relevance of Ethical Salesperson Behavior on Relationship Quality: The Pharmaceutical Industry," Journal of Personal Selling and Sales Management, 11(4), 39-47.

Lambe, C. J. \& R.E. Spekman (1997), "National Account Management: Large Account Selling or Buyer-Supplier Alliance?" Journal of Personal Selling and Sales Management. 17(4), 61-74.

Leigh, T. W. \& P. McGraw (1989), "Mapping the Procedural Knowledge of Industrial Sales Personnel: A Script-Theoretic Investigation," Journal of Marketing. 53(1), 16-34. Leonard-Barton, D. \& I. Deschamps (1988), "Managerial Influence in the Implementation of New Technology," Management Science, $34(10), 1252-1265$.

Locke, E.A., G. Latham, and M. Erez, (1988), "The Determinants of Goal Commitment," Academy of Management, 13(1), 23-39.
MacIntosh, G. and L. Lockshin (1997), "Retail Relationships and Store Loyalty: A MultiLevel Perspective," International Journal of Research in Marketing, 14(5), 487-497.

Moon, M. \& S. Gupta (1997), "Examining the Formation of Selling Centers: A Conceptual Framework," Journal of Personal Selling and Sales Management, 17(Spring): 31-41.

Moore, G.C. \& I. Benbasat (1991), "Development of an Instrument to Measure the Perceptions of Adopting an Information Technology Innovation," Information Systems Research, 2(September), 192-222.

Morgan, R.and S. Hunt (1994), "The Commitment-Trust Theory of Relationship Marketing." Journal of Marketing, 58 (July), 20-38.

Morgan, A.J. and S. Inks (2001), "Technology and the Sales Force: Increasing Acceptance of Sales Force Automation," Industrial Marketing Management, 30(5), 463-472.

Moriarty, R.T. and G.S. Swartz (1989), "Automation to Boost Sales and Marketing." Harvard Business Review, January-February, 100-108.

Nunnally, J. C. and I. Bernstein (1994), Psychometric Theory, 3rd ed., New York: McGraw-Hill.

Park, Chan Wook (2004), "A Study of Organizational Factors For the Activation of CRM: Learning Organizational Theory Approach," Asia Marketing Journal, 6(3), 1-26. 
Park, J.E. and B.B.Holloway (2004), “Adaptive Selling Behavior Revisited: An Empirical Examination of Learning Orientation, Sales Performance and Job Satisfaction," Journal of Personal Selling and Sales Management. 23(3), 237-249.

Parker, D. (1995), "Privatization and Agency Status: Identifying the Critical Factors for Performance Improvement," British Journal of Management, 6(1), 29-44.

Podsakoff, P.M., S.B. MacKenzie, J. Lee, and N.P. Podsakoff (2003), "Common Method Biases in Behavioral Research: A Critical Review of the Literature and Recommended Remedies," Journal of Applied Psychology, 88(5), 879-903.

and D.W. Organ (1986), "Self-

Reports in Organizational Research: Problems and Prospects," Journal of Management, 12(4), 531-544.

Prahalad, C. K. and G. Hamel (1990), "The Core Competence of the Corporation," Harvard Business Review, 68(3), 79-91.

Rangarajan, D., E. Jones, and W. Chin (2005), "The Impact of Sales Force Automation on Technology-related Stress, Effort, and Technology Usage Among Salespeople," Industrial Marketing Management, 34(4), 345-354.

Rivers, L. M. and J. Dart (1999), "Sales Technology Applications: The Acquisitions and Use of Sales Force Automation by MidSized Manufacturers," Journal of Personal
Selling \& Sales Management, 19 (Spring), 59-73.

Rust, R. T., K.N. Lemon, and D. Narayandas (2004), "Customer-centered Brand Management," Harvard Business Review, 82(9), 110-118.

Schillewaert, N., M. Ahearne, R. Frambach and R. Moenaert (2005), "The Adoption of Information Technology in the Sales Force," Industrial Marketing Management, 34(4), 323-336.

Sheth, J. N. and A. Parvatiyar (1995), "Relationship Marketing in Consumer Markets: Antecedents and Consequences," Journal of the Academy of Marketing Science, 23(4), 255-271.

Speier, C. and V. Venkatesh (2002), "The Hidden Minefields in the Adoption of Sales Force Automation Technologies," Journal of Marketing, 66(July), 98-111.

Stoddard, J., S. Clopton, and R. Avila (2002), "Salesforce Automation: An Exploratory Study on Sales Professionals' Perceptions of Performance Benefits," Marketing Management Journal, 12(2),1-9.

Sujan, H., B.A. Weitz, and N. Kumar (1994), "Learning Orientation, Working Smart, and Effective Selling," Journal of Marketing. 58(July), 39-52.

Swenson, M.J. and A. Parrella (1992), "Cellular Telephones and the National Sales Force," Journal of Personal Selling and Sales Management, 12(4), 67-74. 
Taylor, T.C. (1993), "Getting in Step with the Computer Age," Sales and Marketing Management, March, 52-59.

Teece, D. J., G. Pisano, and A. Shuen (1997), "Dynamic Capabilities and Strategic Management," Strategic Management Journal, 18(7), 509-533.

Venkatesh, V. and F.D. Davis (2000), "A Theoretical Extension of the Technology Acceptance Model: Four Longitudinal Field Studies," Management Science, 46(2), 186204.

Verity, J.W. (1993), "Taking a Laptop on a Call: Technology is Turning Selling from a Black Art to a Science," Business Week, No. 3342, October 25, 124-125.

Webster, F. (1992), "The Changing Role of Marketing in the Corporation," Journal of Marketing, 56 (Fall), 1-17.

Wedell, A. and D. Hempeck (1987), "Sales Force Automation - Here and Now," Journal of Personal Selling and Sales Management, 7(2), August, 11-16.

Weitz, B. A. and K.D. Bradford (1999), "Personal Selling and Sales Management: A Relationship Marketing Perspective," Journal of Academy of Marketing Science, 27(2), 241-254. 